\title{
AN EIGHTEENTH-CENTURY MEDICAL HEARING AND THE FIRST OBSERVATION OF TROPICAL PHAGEDAENA
}

\author{
by
}

\author{
I. D. R. BRUIJN and G. W. BRUIJN *
}

Scarcely a week passes in Western countries without the media regaling their citizens with accounts of yet another lawsuit (whether compensational or penal) against a physician whose professional incompetence, ignorance, or negligence has seriously impaired a patient's health or has even cost a life.

The substantial increase in the frequency of such court cases since the 1950s may appear to be indicative of democratization and the growing self-assertion of once hierarchically-subjugated masses. Such cases serve the good of a great many people involved, even if their real ins-and-outs remain largely obscure to the public, journalism being intrinsically beset with a lack of specific medical knowledge and with the daily pressure to provide the latest news.

Are these lawsuits, medico-legal conflicts, and hearings really a new feature of modern times? Of course they are not. The first liability and compensation acts passed in England and Germany around the 1870s rapidly generated a whole industry of lawsuits. As the next pages attempt to show, the unruly Dutch set a precedent for doctors' hearings at least a century earlier. The case we came across in Jakarta's National Archive is, to our knowledge, the first of its kind in this respect. We disregard for the moment the intercollegial conflict aired in 1750, as narrated by Titsingh: the Titsingh case was altogether different, for it related to the admittance of barbers and Jews to the Amsterdam surgeons' guild, along with the usurpation of examination fees; it was, moreover, a case which remained "in the family". 45 The following pages show that an avant-la-lettre case from the past harbours more than meets the eye. In addition to reconstructing the case, we have tried to examine the endemic disease that lay at its roots and, in retrospect, to pose a satisfactory diagnosis of what the patients really must have been suffering from.

* Iris D. R. Bruijn, Hist. Drs., G. W. Bruijn, MD, D.Sc., Soestdijkseweg 384 N, 3723 HL Bilthoven, The Netherlands.

The advice and help generously extended by Professors $\mathbf{H}$. Cook, H. Beukers, J. R. Bruijn, and A. M. Luyendijk-Elshout and Drs M. A. W. Algera-Van der Schaaf is hereby gratefully acknowledged; we also thank Mr G. van der Giessen, medical photographer, for his expert production of the illustrations.

${ }^{1}$ A. Titsingh, Geneeskonst der Heelmesters tot dienst der Zeevart, 1st ed., Amsterdam, Adr. Wor, 1752 , pp. 406-23; D. de Moulin, A history of surgery, Dordrecht, Martinus Nijdhoff, 1988, p. 169. 
THE SHIP

On 10 May 1774, the Ouwerkerk sailed from the harbour of Rammekens in the Dutch province of Zeeland for the Dutch East Indies. A crew of 366 served under her captain, Johan Splinter Stavorinus. The Ouwerkerk, built in 1768 in the Zeeland yard, was, at 1,150 metric tons, one of the larger East Indiamen. ${ }^{2}$ Her length must have been about 160 and her beam about 40 Amsterdam feet. ${ }^{3}$ This voyage was her third, after a maiden trip to the East Indies in 1770 and another in 1772.

The journey was relatively uneventful. The ship arrived at the Cape of Good Hope on 10 September 1774, where she stayed for a month, having to unload the ill among the crew into hospital. The Ouwerkerk left the Cape on 9 October and arrived in Batavia on 19 December 1774. The total sailing time was approximately seven months, slightly below the average. During the outward voyage, seventy-nine of the crew died, or 22 per cent. ${ }^{4}$ There were four surgeons on board: Leendert Vinke (chief or First Surgeon, i.e. opperchirurgijn or oppermeester), assisted by Isaak Frey and Carel Fredrik Langhaus (Second Surgeons, onderchirurgijns or ondermeesters), and Franciscus Scheltens (Third Surgeon, derde meester). ${ }^{5}$

In Batavia, the crew was largely replaced and the Ouwerkerk kept a skeleton crew of twenty-five hands. ${ }^{6}$ The sources give no figures for the crew when the ship started its next journey; however, for the relatively short trip that was to come the number would not have exceeded 150 .

After Christmas, the ship weighed anchor again on an intra-Asiatic journey for Ambon via Macassar, with the same skipper, but with a new First Surgeon, Adriaan van Brakel, assisted by Isaak Frey as Second Surgeon. ${ }^{7}$ The objective was to buy cloves and nuts as well as to take a new Governor, Bernardus van Pleuren, to Ambon to replace Governor Joan Abraham van der Voort. ${ }^{8}$ The Ouwerkerk first sailed along Java's north coast, stopping at various ports to deliver and take on merchandise, and then crossed the Java Sea to its first destination, Macassar (today's Ujung Pandung), the main port and capital city of the island of Celebes (Silawesi). The journey, which, if direct, would have taken a week, because of the trading took about five weeks (see the map). An epidemic arose on board and spread quickly among the crew. The ship arrived at Macassar with thirty-nine sick on 9 February 1775. By the time she reached Castle Nieuw Victoria, on the isle of Ambon, on 9 March 1775, the number had risen to sixty-three. ${ }^{9}$

\section{THE COMPANY}

The Ouwerkerk belonged to the Dutch East India Company (VOC), an organization

2 J. R. Bruijn et al. (eds), Dutch-Asiatic shipping in the 17th and 18th centuries, vol. 2, Rijks Geschiedkundige Publicatiën 166, The Hague, 1979, p. 662.

${ }^{3}$ One Amsterdam foot $=28 \cdot 3 \mathrm{~cm}$.

4 The average death rate on the outward journeys in the period 1770 to 1775 was 23 per cent. J. R. Bruijn, 'De personeelsbehoefte van de VOC overzee en aan boord, gezien in Aziatisch en Nederlands perspectief', Bijdr. Meded. Geschiedenis der Nederlanden, 1976, 91: 218-48, p. 223.

${ }^{5}$ State Archives, The Hague (ARA), VOC 13203.

${ }^{6}$ ARA, VOC 11815.

7 Ibid.

${ }^{8}$ ARA, VOC 3439 , f. 1 , and VOC 805 , f. 434.

9 ARA, VOC 349 , f. 1 ; but see note 22 below. 


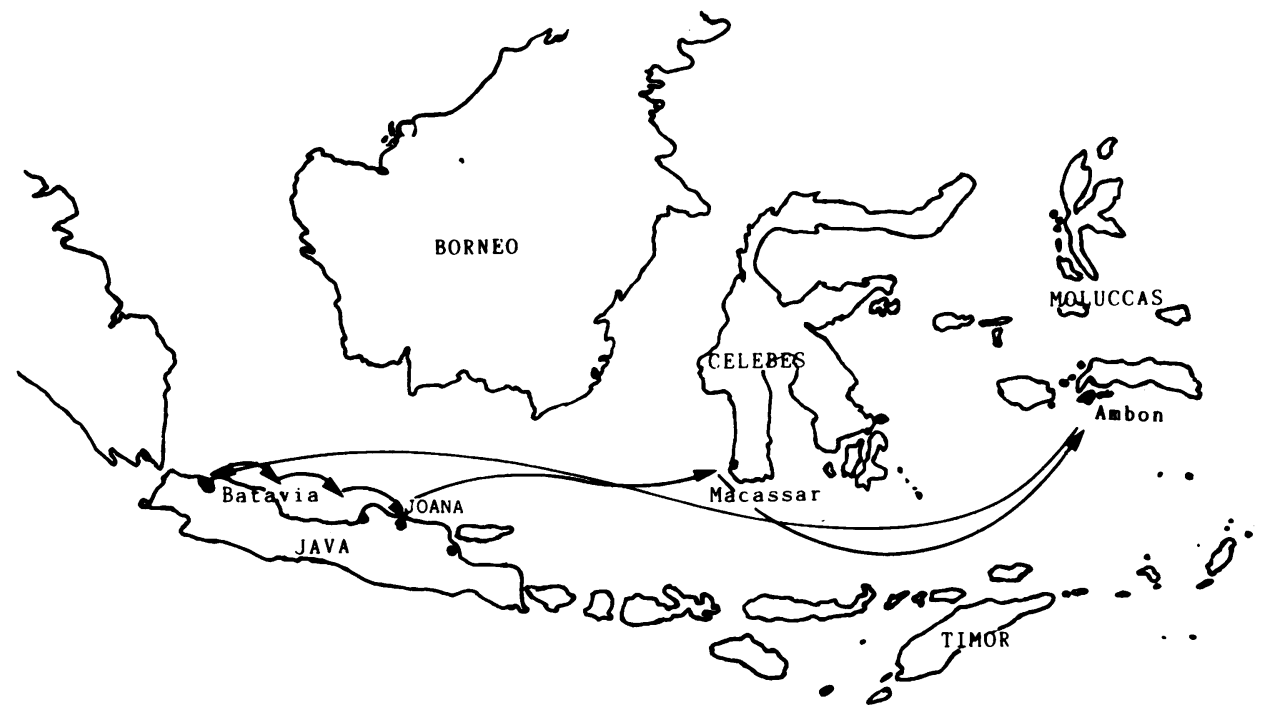

founded in 1602 and dissolved in 1795. The VOC's objective was to channel profits from the trade between Europe and Asia and within Asia itself back to The Netherlands. To achieve this aim, it built ships and fitted them out, constructed warehouses, forts, harbours, and even cities overseas, and conquered territories in Asia. The government of the Republic of the United Netherlands officially endorsed this policy by a charter of 1602 , in which it transferred important privileges to the VOC, the prime one being the Company's exclusive right to fit out ships for trade east of the Cape of Good Hope or through the Straits of Magellan. ${ }^{10}$ The VOC was also authorized to make treaties with rulers and states in Asia, to build fortifications, and to enlist soldiers: in short, it could behave as a "state outside the state".

The Board of Directors of the VOC was called the Heren XVII (the Seventeen Gentlemen). Under their aegis, the Company was compartmentalized into six cities or chambers (Kamers) from whose corporate fusion the Company was initially born and which were proportionately represented on the Board: Amsterdam, Middelburg (Zeeland), Hoorn, Enkhuizen, Delft, and Rotterdam. Each of these cities independently fitted ships out, assembled a crew to sail them, and sent them to the East. Over 4,700 outward voyages were made during the existence of the Company, with nearly one million people boarding from the Republic. Roughly one-third came back. ${ }^{11}$

An administrative centre was necessary in Asia where the employees traded, conquered, lived, and died. Jan Pieterszoon Coen conquered Jakarta, on the island of Java, in 1619 and rechristened it Batavia. The central government (Hooge Regeering) of Asia, which consisted of the Governor-General and the Council of the Indies, took p. 6.

${ }^{10}$ Bruijn et al., op. cit., note 2 above, vol. 1, Rijks Geschiedkundige Publicatiën 165, The Hague, 1987,

${ }^{11}$ Ibid., p. 143. 


\section{D. R. Bruijn and G. W. Bruijn}

up residence in Batavia. On the Council as a whole rested the obligation of reporting annually on the state of affairs in Asia. ${ }^{12}$ All possessions, factories, and ships in Asia were under the authority of the Hooge Regering in Batavia. Local government was a mirror image of central government. Important possessions, like Ambon and Macassar, were administered by a Governor(-Director), assisted by a Council of Police. ${ }^{13}$ After 1650 , the judicature in Asia was vested in a nine-member Council of Justice, ${ }^{14}$ to which all criminal and civil cases were entrusted. ${ }^{15}$ The President of the Council was always a Raat-(extra)ordinaris (Councillor (Extra)Ordinary) from the Council of the Indies. ${ }^{16}$

\section{THE INTRA-ASIATIC VOYAGE}

What happened during the voyage of the Ouwerkerk between Batavia and Ambon? The following narrative is based on a 44-octavo-page document in the National Archives in Jakarta. ${ }^{17}$ With one exception (see note 39 ), no other reference to the events has so far been found.

According to the journal of First Surgeon Van Brakel, the outbreak started with diarrhoea, dysentery, and continuous and intermittent fever among the crew, most of whom were youths from Holland and from Batavia Hospital who had been obliged to serve as if they were healthy. Many of them, initially, had small leg ulcers which apparently were not malignant. The disease became almost universal; some had a tense bloated belly as in tympanites ("tympany") due to intestinal atonia, became emaciated with serous (watery) dysentery, and had sharp abdominal pains. Others, who had been ill in Batavia, relapsed, having drunk too much brackish water (not of the best quality off Batavia) after heavy work, before they laid down to sleep in the cold evening air without sufficient covering. They mixed the water with tamarind, which Van Brakel had forbidden them to do; he also ordered them not to sleep outside. He dressed the ulcers with "Tinct. Alöes et myrrhae" for about ten days. Seeing no improvement, he prescribed "Bals. Unguent. Basilic. c. Egyptiae", but the ulcers increased in size with irradiating bloody streaks on the limbs. He therefore resorted to "Tinct. c. Oleo Terebinth", as he diagnosed ruptures of vessels and tissue, blood coagulation, putrefaction, and gangrenous ulcer borders. The tissue surrounding the ulcers was indurated (hardened) and inflamed with putrefaction and the secretion of coagulated blood. In a few days, the ulcers reached the size of a spread-out hand. He dressed them three times a day, without avail. The ulcers eroded the skin, muscles, tendons, and vessels, exposing the rotting bones. He prescribed cataplasms, sprayed with "Spirit. Arak Camphor.", cleaned the ulcers with spirits, performed "V.S." (venesection),

12 Ibid., p. 121.

13 Ibid.

14 Ibid.

${ }^{15}$ P. Van Dam, Beschrijvinge van de Oostindische Compagnie, Rijks Geschiedkundige Publicatiën 87, The Hague, 1943, p. 49.

${ }_{16}$ Ibid., p. 81 .

${ }^{17}$ Arsip Nasional, Jakarta (ANJ), Ambon 1775, nr. 15/98, marine 43. This document when arranged in chronological order, consists of seven separate reports and minutes: A. Macassar, 9 February 1775; B. Macassar, 10 February 1775; C. Macassar, 10 February 1775; D. Ambon, 10 March 1775; E. Ambon, 25 May 1775; F. Macassar, 1 June 1775; G. Batavia, 10 July 1775. 


\section{An eighteenth-century medical hearing}

prescribed laxatives and purgatives, gave cooling mixtures and daily escharred (i.e., cut away the necrotic tissue) where necessary, and prescribed Peruvian bark for internal use.

Of the 39 sick, 16 were soldiers, 12 were sailors, 8 were "Moors", 1 was a sail-maker, 1 a bullet-satchel maker, and 1 a quartermaster.

On the ship's arrival at Macassar, Mr A. Peters and Mr J. Raket, the trustees or Buiten-Regenten of the Fort Rotterdam Hospital, immediately visited the thirty-one European and eight black patients, in the presence of the hospital's two First Surgeons (Mr C. Kirsten and Mr G. Braun) and A. van Brakel. The patients visited by this committee of five, on being questioned in turn, unanimously imputed their condition to Van Brakel, who had, they said, initially refused to dress many of them, often even removed dressings, and refused their request for new lint, arguing that he had used up all the linen and medicines. Moreover, their beds had been placed under the fo'c'sle in front of the hawsehole, and had therefore been continuously wet by the incoming sea-water.

Peters and Raket asked Van Brakel whether he had informed the Captain of the total amounts of medicines consumed and of the location of the patients. Van Brakel replied that he had never done so in his career. He told them that not only had he taken all appropriate action and in doing so used up almost all the dressings and medicines, but he had also given the patients materia medica owned by him personally.

The findings of Peters and Raket were reported to Paulus Godofredus van der Voort, the Governor of the coast of Celebes (not to be confused with Joan Abraham van der Voort, Governor of Ambon).

The next day, 10 February, the surgeons of the hospital presented to the Governor of Celebes a list of the lesions, with details about the size and site, observed in the thirty-nine patients (plate 1). Kirsten and Braun had found that all of them had "malignant", putrefying and necrotising ulcers that involved the calf, shin, ankle, foot (heel or instep), and toes. The ulcers, on the average measuring 2.5 by 3.5 inches with an occasional maximum size of 7.5 by 9 inches, spread by eating away tendons and muscles and led to gangrene, caries, and necrosis of the exposed bones, with occasional loss of one or more toes. The ulcers were single in 35 instances, and multiple in 3 . The shin was involved in all 11 patients, the foot in 7 (with loss of toes in 2), the big toe in 5 (with loss of it in 2), the ankle in 4, the Achilles tendon in 4, and the heel in 2.

As Kirsten and Braun did not want to be held responsible for the patients' possible deaths, or loss of the use of the legs, they asked the Governor to assign two officials to examine the patients in the presence of Van Brakel (an odd request, since this had already been done, according to the trustees' report of the previous day). They also asked for an allocation of linen, arak, and Dutch vinegar, having already used half a piece of guinese (or Guinea cloth) for dressings, as none of the patients had arrived in the hospital with adequate dressings. Further, they together drew up a list of the contents of Van Brakel's surgeon's chest. In this list there is, however, no comparison made between what they measured and what the fully-supplied chest had contained on the day of the ship's departure from Batavia. Analysis of the list discloses the curious fact that nearly all the medicines remaining in the chest, according to Kirsten's and Braun's reckoning, weighed out in nicely-rounded figures: 1 or 2 pounds, and 2 or 6 ounces. 


\section{D. R. Bruijn and G. W. Bruijn}

The Governor, having read the reports, called for a meeting of the Police Council in Castle Rotterdam on 10 February 1775 , only a day after the ship's arrival. There was clearly a confusion about the number of patients, as the Governor wrote of forty-eight patients sent by Van Brakel to the Hospital. The Governor summarized the actions already taken, i.e., the trustees asking the patients what they believed to be the cause of their condition, and the patients' medical examination by the two surgeons. Both trustees and surgeons believed that Van Brakel had lied and neglected his duty, and that he was ignorant and negligent, because they considered his diagnosis and treatment to have been erroneous.

After much discussion, and in view of the fact that Mr van Pleuren, the new Governor of Ambon, had to sail with the ship to Ambon, which left no time for further inquiry, Governor van der Voort proposed to forward all relevant minutes and reports to the ministers at Ambon with the request to deal with Van Brakel as they saw fit.

The Ouwerkerk set sail for Castle Nieuw Victoria at Ambon, with the thirty-nine patients on board. During the voyage the number of sick increased: when she arrived at Ambon on 9 March 1775, she carried either fifty or sixty-three patients (the sources conflict: see note 22 below), who were put into the hospital. The reports made in Macassar were taken to the Ambon government, which decided to call for an immediate meeting. The Police Council convened the next day and argued that the quality of Van Brakel's management could only be judged by someone whose daily work was naval surgery, i.e., the Chief Surgeon and Visitor of Batavia, to whom all surgeons, whether arriving from Holland or from the Buijten-Comptoiren (overseas trading posts), had to submit their journals for examination.

Accordingly, the Council decided to forward all the relevant documents from Macassar and Ambon to the Governor-General at Batavia. On 25 May, the Ambon Governor and his Council met again to address a letter to the Governor-General, repeating the Macassar suspicion that Van Brakel had neglected his duty. However, the letter also pointed out that the disease, striking as it had so many on board, really had to be considered as a punishment from Heaven rather than the result of any neglect of duty: it had turned out that, despite all appropriate measures and medication during the time the ship was lying at anchor off Ambon, the number of those weak with ulcers increased daily.

The Ouwerkerk set sail again with all the documents aboard, back to Batavia. In the meantime, the Celebes Governor had sent a memo to the Governor-General on 1 June, to make sure that the Ambon ministers should have no chance of forgetting the case. The Ouwerkerk entered Batavia's harbour on 26 June, and all the documents were sent to the Governor-General.

In Batavia, Van Brakel drew up a statement (apologia) to meet the accusations of mismanagement and neglect of duty for Johannes Themans, Chief Surgeon and Visitor of Batavia. In this, Van Brakel pointed out that most of the crew were scorbutic novices not used to the tropical climate, who had come from Inderland ${ }^{18}$ and from the

\footnotetext{
${ }^{18}$ We could not find the meaning of the word Inderland. It could be that Van Brakel meant Ingeland, i.e., land inside the dykes surrounding Batavia. F. De Haan, Uit de Nadagen van de Loffelijke Compagnie, Amsterdam, E. M. Querido, 1984, p. 260.
} 

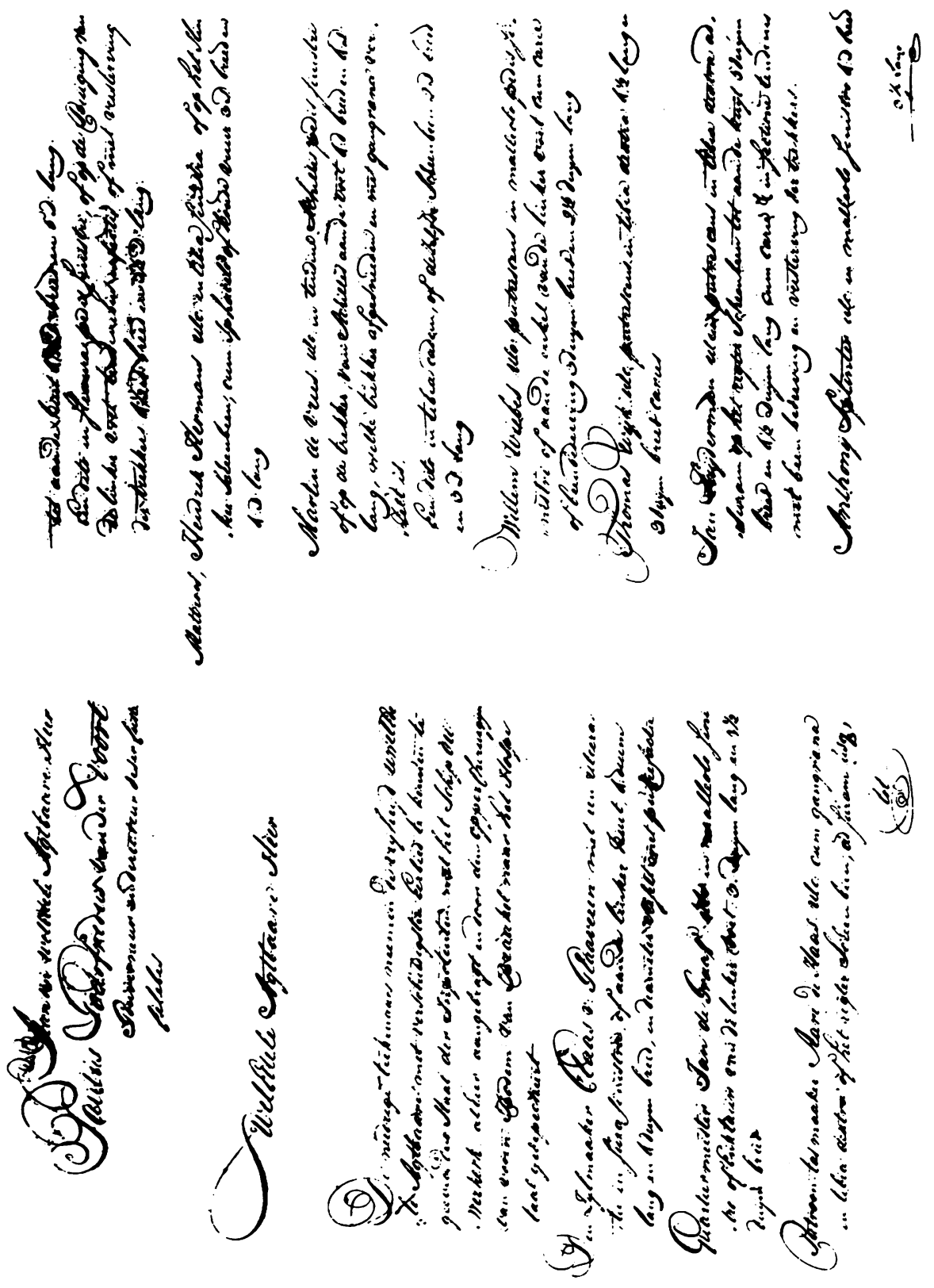

Plate 1: Page from the text of Peters and Raket's report to Governor van der Voort. 

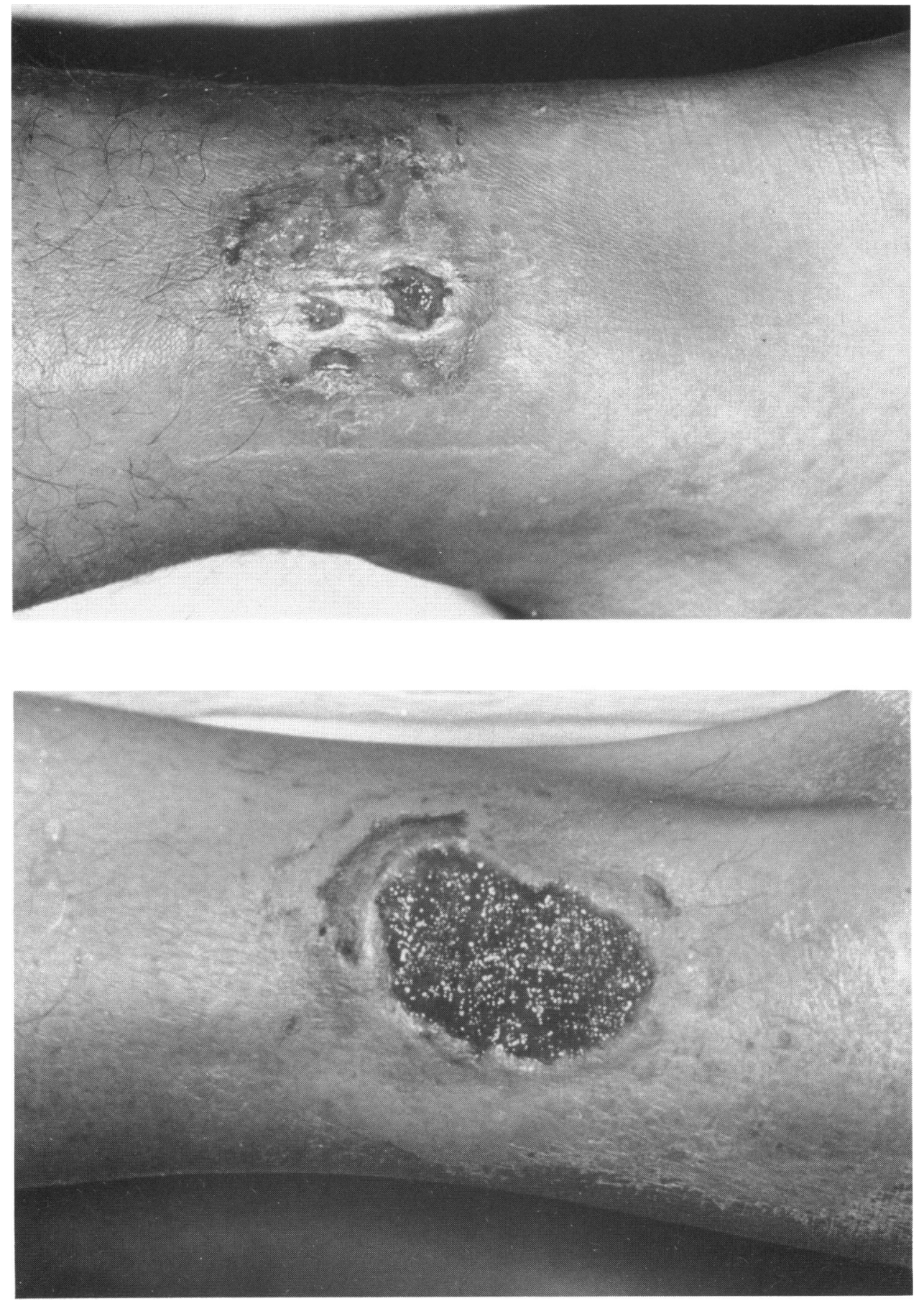

Plate 2: Ulcus phagedaenicum tropicum, outer ankle, (top) in the first stage of sloughing, (bottom) in the third stage, after the slough has come off. 


\section{An eighteenth-century medical hearing}

Hospital, and who were put on board for another journey without sufficient time on land to recuperate from their illnesses. Two had become ill immediately. Some of them suffered from small, but very "malignant" leg ulcers, many had watery diarrhoea, fully described in the ship's Journal, and some had dysentery and fever. Because, he wrote, the abdominal diseases and fever took a largely favourable turn with only(!) ten deaths during the journey, he refrained from further comment on them, the more so since the charge laid against him concerned the manifold malignant ulcers (hypersarcotic cum sphacelo, i.e., sloughing, necrotising, and granulomatous). The treatment consisted of antiseptics, balsams and acids, as well as Ol. Terebinth, Spirit. vitriol., Ung. Egypt. alb. et cyprin., Spir. Camphor., Spir. sal. ammon., Tinct. alöes et myrrh., and Cortex Peruv., all medicines prescribed and recommended by famous doctors, and approved of in writing by the Ambon First Surgeons, Theodorus van Lint and Gerardus Hengeveld. Van Brakel proceeded to argue that,

1. "Impotents" (invalids) are unable to judge professional (lege artis) treatment;

2. They have merely repeated a song given to them, because the facial expressions of and whispered conversations between two surgeons and two trustees during the visitation at Macassar could not have failed to convey these high officials' doubts with respect to the defendant;

3. The surgeons Kirsten and Braun are not professors, and certainly had their own advantage in mind as well as their own reasons to report as they did (this understatement sarcastically refers to the fact that Kirsten and Braun came to the East Indies as soldiers); ${ }^{19}$

4. The Macassar Government, after first rejecting his request for additional medication as being unrealistic, later provided it;

5. The Ambonese surgeons Van Lint and Hengeveld testified to a daily-growing number of these ulcer patients and rather than ascribing this to a punishment from Heaven, Van Brakel interprets the cause to be an alkaline, scorbutic, and malignant mixture of humours, as described by Boerhaave and Hoffman, ${ }^{20}$ as he has all too often seen this disease in the hospitals and on the ships;

6. He applied dressings three times a day, as his Captain testified, even during the night and from his private stock of 16 pounds of lint (bought for 12 stuijvers per pound at Batavia's tailor Bartels), because a single dressing might require half a piece of guinese. Indeed, he occasionally refused abnormally frequent changes of dressings, and also refused lint when he had applied a vitriolcrust or Escar, because to do otherwise would have been a professional error: one may only wet the crust with tinctures;

\footnotetext{
${ }^{19}$ ARA, VOC 5258. J. R. Kirsten, born in Wartob, Germany, came to the East Indies in 1761 with the ship Wiltrijk, as a soldier. His pay was then 9 guilders per month. In 1770 he was made Chief Surgeon of the Castle at Macassar, at 40 guilders a month. In 1773 he was again promoted, to a salary of 60 guilders a month. J. G. Braun, born in Etterleben, Germany, came to the East Indies in 1765 with the ship Voorland as a soldier earning 9 guilders a month. In 1773 he was made Chief Surgeon of the local hospital at Macassar, at 36 guilders a month.

${ }^{20}$ Van Brakel referred to Boerhaave's "Inst. de Acrimonia alcalina" and "Aphorismi", "cap. de scorbute", and to Hoffman's "Medic. Ration Syst.", book 5.
} 


\section{D. R. Bruijn and G. W. Bruijn}

7. The location onder de bak (fo'c'sle) near the hawsehole was the safest and quietest place because, (a) there were too many patients to remain under the halfverdek (upper-deck), (b) sailing along Java's coast involved continuous loading and unloading, and the patients would otherwise have been in the way, (c) the location was chosen after consultation with the Captain and others. And, he had already asked the Captain for additional medicines in Joana; ${ }^{21}$

8. Kirsten and Braun did not weigh or measure the medications in the chest, nor tick them off by jotting little marks beside each item; and he had not stated that he had used up all the medications, but only all that were relevant and appropriate. Kirsten and Braun come from Germany, where they were evidently taught to apply fatty ointments on such ulcers, and they therefore declared that all the relevant drugs were still present. He had to keep a small reserve, because on any journey serious accidents and amputations must be foreseen.

9. He has never been charged before and asks for a favourable certificate.

As the case was being discussed in Batavia by the various Councils, more information was requested from the Ambon Governor J. A. van der Voort. On 20 September 1775, Van der Voort wrote to P. A. van der Parra, Governor-General at Batavia, that the Ouwerkerk had put ashore at Ambon carrying forty-eight Europeans and fifteen blackamoors with the illness. ${ }^{22}$ On 12 December, the Governor-General and the Council of the Indies reported to the Heren XVII in the Republic, stating that the Ambon Ministers had made the "contrary remark" to all the Macassar accusations that the large number of sick was the result of a punishment from Heaven on ship and crew, and was certainly not the result of negligence on the part of the First Surgeon A. van Brakel; he concluded that he had done his duty and he was acquitted by them. ${ }^{23}$

The case fizzled out. Van Brakel continued to serve on the VOC fleet until his death a few years later.

\section{THE SURGEON}

Adriaan van Brakel was born in Delft, in $1733 .{ }^{24} \mathrm{He}$ entered the service of the VOC in 1751, and rose from derde meester to oppermeester in thirteen years' service on six voyages between the Dutch Republic and the East Indies and on a number of intra-Asiatic journeys. ${ }^{25}$ This implies that he had acquired above-average experience of tropical diseases both at sea and on land. He died in 1781, during another intra-Asiatic journey, and was interred in Cochin, the Dutch trading post in India's Malabar province. Having remained unmarried, he left all he possessed to his sister Catherine and her children, as stipulated in the will he had made on 11 March $1756 .^{26}$

${ }^{21}$ Djoewana is the port at the mouth of the Juwana River, in Japara County $\left(111^{\circ} 15^{\prime}, 6^{\circ} 40^{\prime}\right)$.

22 ARA, VOC 3439, f. 7. The documents in the ANJ (note 17 above) variously state that fifty and sixty-three sick arrived in Ambon in March.

${ }^{23}$ ARA, VOC 3421, ff. 596-599.

${ }^{24}$ Municipal Archives, Delft, Division 45, Requestboek, 3 March 1756.

25 ARA, VOC 13997, 14001, 14007, 14020, 14024, 14030.

${ }^{26}$ Municipal Archives, The Hague, Notariëel, no. 3690. 
THE DISEASE

In order to understand why a certain disease could rapidly become epidemic on board, the following should be taken into account.

During the VOC's two centuries of existence, it became progressively more difficult to recruit sufficient manpower and to maintain quality in personnel selection, particularly in the eighteenth century, because the Company's fleet and the number of voyages per year rose considerably due to expansion in Asia. ${ }^{27}$ Not only were many men in bad health on boarding, their accommodation on the ships left much to be desired. Whereas officers and passengers had separate cabins and shared a cabin for meals and social intercourse, the men were accommodated in the orlop, between the cannons. On this, the lowest deck, ventilation was minimal. The hammocks of sometimes 300 or more men (in a ship at most 160 feet long, and 40 feet wide) hung right against one another. Fresh air entered through the hatches and open portholes, all but one of which, however, stayed closed in bad weather. ${ }^{28}$ Especially in the tropics, the orlop must have been almost unbearable because of the heat, vermin, overcrowding, and stench.

Under such circumstances, illness and death were frequent visitors. Injuries were easily sustained during the hard and heavy work as well as during battle, though they were never a cause of high death-rates. The ship's surgeons were generally quite capable of managing them.

Such was not the case with diseases caused by lack of vitamins (beri-beri and scurvy), which usually manifested themselves after three or four month's uninterrupted stay on the high seas. The diet on board, though rich, was deficient in vitamins. ${ }^{29}$

Soon after embarkation, infectious diseases (dysentery, typhus, typhoid, pneumonia, and venereal diseases) took their toll, much earlier than the deficiency diseases (beri-beri and scurvy). Over 140 years, the death rate averaged 10 per cent rising to 23 per cent between 1695 and 1700 during wartime, with the resultant low quality of crews; in the second half of the eighteenth century, despite advances in medicine and because of the factors mentioned above, the total death rate rose to about 12 per cent, again shooting up to 23 per cent between 1770 and 1775 (see table 1). ${ }^{30}$

The clinical data recorded by Van Brakel and his accusers Kirsten and Braun over two centuries ago are exemplary and precise.

The outbreak of ulcers appeared in a young, inexperienced, non-acclimatized and partly-ill crew. The ulcers, involving the lower leg, foot, and toes exclusively, gradually spread in size, were putrefying (pus-forming) and foul-smelling, developed a sanguineous-coagulated crust that shed a slough (cum sphacelo), and showed bloody

${ }^{27}$ Bruijn et al., op. cit., note 10 above, p. 151.

${ }^{28}$ G. F. Pop, De geneeskunde bij het Nederlandsche zeewezen, Batavia, L. S. A. M. von Römer, 1922 (first published as an article in the Geneeskundig Tijdschr. voor de Zeemagt, 1866-68), p. 221.

${ }^{29}$ J. van Beylen, Schepen van de Nederlanden, Amsterdam, 1970, p. 244. ARA, 1.10.69. Collectie Radermacher no. 89, Lijst van victualiën en ordre op Rantsoenen, \pm 1724 ; and ARA, VOC 4967 I, victualielijst 1786. Curiously, in strict obedience to a resolution of the Heren XVII, the ships carried enough water and food for approximately nine months, i.e., for the whole journey to Batavia, in spite of the obligatory one-month stay at the Cape. The daily meals of the crew consisted of groats mixed with prunes or raisins for breakfast and, for lunch and dinner, peas or beans supplemented with fish, meat or bacon.

${ }^{30}$ Bruijn et al., op. cit., note 10 above, p. 163. 


\section{D. R. Bruijn and G. W. Bruijn}

Table 1: Average death rate on the VOC's outbound voyages ${ }^{31}$

\begin{tabular}{lclc}
\hline Decade & Death rate & Decade & Death rate \\
$1620-1630$ & $16 \cdot 8 \%$ & $1700-1710$ & $7 \cdot 4 \%$ \\
$1630-1640$ & $6 \cdot 2 \%$ & $1710-1720$ & $6 \cdot 8 \%$ \\
$1640-1650$ & $8 \%$ & $1720-1730$ & $8 \cdot 9 \%$ \\
$1650-1660$ & $7 \cdot 6 \%$ & $1730-1740$ & $12 \cdot 9 \%$ \\
$1660-1670$ & $9 \cdot 1 \%$ & $1740-1750$ & $13 \cdot 3 \%$ \\
$1670-1680$ & $9 \%$ & $1750-1760$ & $9 \cdot 3 \%$ \\
$1680-1690$ & $9 \cdot 7 \%$ & $1760-1770$ & $11 \%$ \\
$1690-1700$ & $14 \cdot 7 \%$ & $1770-1780 *$ & $15 \cdot 1 \%$
\end{tabular}

*In the years $1770-1775$, the average death rate on outbound voyages rose to 23 per cent.

streaks (which means lymphangitis or phlebitis) irradiating from the ulcers' hardened and "flesh-forming" ("hypersarcotic" or granulomatous) borders, meanwhile eroding and necrotising such tissues as fascia, tendons, muscles, and nerves (which explains the pain), exposing and eating away the bones, and leading to the loss of one or more toes.

Van Brakel quite correctly ascribed part of the disease's pathogenesis to the debilitated state of the patients, which may be described in modern terms as "weakened resistance", or "immunological incompetence" due to malnutrition, avitaminosis, dysentery, and fever. As a true medical man, he searched for a common denominator. In that pre-Pasteurian era he would not have had the faintest idea of an infective micro-organism. A modern physician would think of infected leather footwear (shoes, boots), but, clearly in the tropics the crew did their jobs on board barefoot. Having been trained in the paradigm of "humoral pathology", he sought the common denominator in an "alkaline-scorbutic malignancy" of the crew's bodily juices rather than in any notion of a "punishment from Heaven".

Apart from the factors of malnutrition and intestinal disease, locating the patients in a site where they were continuously sprayed by the bow-waves must be considered as a less than judicious decision.

For a twentieth-century physician, identifying the epidemic prevalent on board the Ouwerkerk is easy. Thanks to the documented observational prowess of the seasoned Van Brakel, a number of diseases causing exclusive ulceration of the legs can be immediately dismissed from differential-diagnostic consideration: varicose, diabetic, traumatic, neoplastic, tuberculous, and syphilitic ulcers. Framboesia (yaws, caused by the Treponema pertenue) and Madura foot (caused by Actinomyces) require a bit more thought. These two can also be discarded, however, because of the generalized spreading as well as absence of the putrefying necrosis in the first, and the typical roe-like discharge of the second. The diphtheric (tropical) ulcer is multiple. ${ }^{32}$ That leaves ulcus phagedaenicum tropicum as the only possibility. This ulcer (plate 2) is caused by what was once thought to be the Treponema schaudini ${ }^{33}$ and which is now

\footnotetext{
31 Ibid.

32 A. A. Lieblow, P. D. MacLeon, and L. G. Walt, 'Tropical ulcers and cutaneous diphtheria', Arch. int. Med., 1946, 78: 255-95.

${ }^{33}$ H. Vincent, 'Examen bactériologique d'un cas d'ulcère des pays chauds (ulcère de la Guadeloupe)', Ann. Dermatol., 1900, 30: 812-14. Idem, 'Remarques sur l'étiologie, la pathologénie et l'agent pathogène, “Baccillus fusiformis", de l'ulcère phagédenique', Bull. Acad. Méd., 1945, 129: 545-8.
} 


\section{An eighteenth-century medical hearing}

considered to be another spirochaete, the Borrelia vincentis, in conjunction with a mixed fauna of fusobacterium, streptococci and staphylococci. Modern descriptions of this ulcer ${ }^{34}$ are so congruent with Van Brakel's notes that one may confidently conclude that he-and his accusers-made the first observation of this disease.

The source material in Jakarta's National Archive offers two main points for discussion: one medico-legal and one medico-historical.

Neither the Police Council at Ambon nor that at Macassar dared to dirty their hands with this case. The Ouwerkerk returned to Batavia on 26 June 1775, with all pertinent documents from Ambon and Macassar to be dealt with by the authorities. ${ }^{35} \mathrm{~A}$ memo had been sent to the Governor-General on 1 June to make sure that the ministers should stand no chance of "forgetting" the case. No documents of the discussion of "State v. Van Brakel" case at the Council of the Indies have been traced, but such discussion clearly must have taken place.

During the 1770s, Thomas Schippers was the Councillor-Extraordinary of the Council of the Indies as well as the President of the Council of Justice. ${ }^{36}$ After having received all the documents from Ambon, Macassar, and from Johannes Themans, surgeon/apothecary-in-chief, during a meeting of the Council of the Indies, it must have been Schippers who brought the case before the Council of Justice.

The Council of the Indies was under pressure because of the dramatic rise in the death rates on eastbound journeys and because the Heren XVII had ordered it to investigate, when an extraordinary number of ill or deceased people were noticed in a First Surgeon's journals on arrival in Batavia, whether the ship's surgeons had managed the cases correctly, and, if not, to punish them. ${ }^{37}$ The penalties were meted out according to the discretion of the Council of Justice.

Thomas Schippers was therefore obliged to investigate. Accordingly, he must have given all the documents to Johannes Themans, ${ }^{38}$ on the basis of whose findings the Council of the Indies wrote to the Heren XVII on 12 December 1775 that, after careful investigation, they had reached the conclusion that Van Brakel's treatment was quite correct, dutiful, and beyond reproach. ${ }^{39}$

From a purely legal point of view, the handling of the case was bungled, as far as the sources allow one to establish. No proper accusation was made, no proper hearing of the accused was allowed nor proper defence conducted, and no clear verdict reached. If it was an acquittal, no amende honorable was acknowledged; if not, no punishment was undertaken. Of course, procedures in medico-legal cases still had to be formalized. Yet

\footnotetext{
${ }^{34}$ A. G. Apostolides, 'Note on the recent epidemic of tropical septic ulcer in Palestine (tropical sloughing phagedaena)', J. trop. Med. Hyg., 1922, 7(15): 81-8; E. Besnier, L. Brocq, and L. Jacquet, La pratique dermatologique, vol. 4, Paris, Masson, 1940, pp. 715-23; M. Meyer, 'Ulcus tropicum (tropischer Phagedaenismus)', in Handbuch der Haut- und Geschlechtskrankheiten, ed. J. Judassohn, vol. 12, pt. 1, Berlin, Springer, 1932, pp. 108-18; A. Basset, 'Tropical phagedenic ulcer', in Essays on tropical dermatology, ed. R. D. G. T. Simons and J. Marshall, Amsterdam, 1969, pp. 25-33; A. Rook et al., Textbook of Dermatology, 4th ed., vol. 1, Oxford, Blackwell, 1986, pp. 783-4.

${ }^{35}$ ARA, VOC 3419, f. 197, and VOC 3419, f. 197.

${ }^{36}$ ARA, VOC 5022.

${ }^{37}$ ARA, VOC 222, Resolutions Heren XVII 1737-1784, f. 379, resolution of 2 April 1774.

${ }^{38}$ ARA, VOC 806, f. 363 (Resolutions Governor-General and Council of the Indies 1776), 26 March 1776.

39 ARA, VOC 3421, f. 599.
} 


\section{D. R. Bruijn and G. W. Bruijn}

one cannot escape the impression that governmental frustration, strengthened by collegial intrigue, and, finally, an absence of firm and formal justice mark this first case of a medical hearing.

Table 2: Synonyms for tropical (phagedaenic) ulcer

\begin{tabular}{|c|c|c|}
\hline $\begin{array}{l}1856 / 7 \\
1900\end{array}$ & $\begin{array}{l}\text { Vinson: } \\
\text { Le Dantec: } \\
\text { Vincent: }\end{array}$ & $\begin{array}{l}\text { ulcère contagieux de Mozambique "pian" (Réunion) } \\
\text { ulcère phagédénique des pays chauds } \\
\text { ulcère de la Guadeloupe }\end{array}$ \\
\hline 1904 & Regnault: & $\begin{array}{l}\text { ulcère de l'Yemen } \\
\text { plaie malgache } \\
\text { plaie Annamite }\end{array}$ \\
\hline 1905 & Fontoynont: & $\begin{array}{l}\text { ulcère malagache } \\
\text { "Drida" (Mozambique) }\end{array}$ \\
\hline 1922 & Apostolides: & $\begin{array}{l}\text { tropical sloughing phagedaena } \\
\text { Delagoa sore } \\
\text { Rhodesian sore }\end{array}$ \\
\hline 1924 & Corpus: & $\begin{array}{l}\text { Aden ulcer } \\
\text { Malabar ulcer }\end{array}$ \\
\hline 1942 & Earle: & Naga sore \\
\hline
\end{tabular}

As to the second point, Van Brakel and his accusers essentially provided the first accurate description of ulcus tropicum phagedaenicum, an eroding persistent sore well-known in humid tropical countries and well-documented over the last hundred years. ${ }^{40}$ In modern times, adequate treatment prevents the ulcer from assuming the huge and crippling size it attained in earlier days. ${ }^{41}$ The ulcer has been observed in the Caribbean, tropical Africa, India, Indo-China, Indonesia to the Pacific Islands (table 2) and occasionally in countries surrounding the Mediterranean. Since the earliest reports, the ulcus has been recognized to be pandemic, but also as occurring in epidemic outbreaks. The latter is what happened aboard the Ouwerkerk. Besnier et al. declared, in 1914, without specification, that the "princeps" observation of tropical ulcer was made by Vinson in 1852, under the name of ulcère de Mozambique. Vinson's description dates from 1856. ${ }^{42}$ Jadassohn's Handbook of 1932 posits, without further documentation, that the first description of the ulcer stems from Hunter in Jamaica in

${ }^{40}$ T. Corpus, 'A survey of ulcus tropicum', J. Am. med. Ass., 1924, 82: 1192-4; K. V. Earle, 'Tropical ulcer in Trinidad', Trans. roy. Soc. trop. Med. Hyg., 1942, 35: 241-56; M. Fontoynont and E. Jourdran, 'L'ulcère malgache (ulcère phagédénique des pays chauds)', Presse méd., 1905, 13: 25-7; J. Regnault, 'Traitement de l'ulcère des pays chauds', Archs gén. Méd., 1904, 81(ii): 2268-75; G. Keysselitz and M. Mayer, 'Über das Ulcus tropicum', Arch. Schiffs u. Tropen-Hyg., 1909, 13(5): 139-45; C. S. James, 'Tropical phagaedenic ulcer in the Pacific', Trans. roy. Soc. trop. Med. Hyg., 1938, 31: 647-66; I. G. Thomson, 'The pathogenesis of tropical ulcer amongst the Hausas of northern Nigeria', ibid., 1956, 50: 485-95; J. Kariks, 'Tropical ulcer amongst the natives of New Guinea', Med. J. Austral., 1957, 2: 346-50; T. Kuberski and G. Koteka, 'An epidemic of tropical ulcer in the Cook Islands', Am. J. trop. Med. Hyg., 1980, 29(2); 291-7.

${ }^{41}$ R. W. Mendelson, 'An exceptional tropical ulceration', J. trop. Med. Hyg., 1921, 24(24): 317.

42 A search by Mr Rivet, Conservator of the Inter-University Library of Paris, has revealed that Vinson indeed described the ulcer in a "lay" periodical of the Île de Réunion in 1856, and subsequently in two French medical journals in 1857, stressing the contagiousness of the ulcer and its difference from the tuberculous ulcer known locally as "pian". His description perfectly matches those of modern authors. P. A. Vinson, 'Ulcère contagieux de Mozambique', Moniteur de l'île de la Réunion, 1856, no. 441; idem, Gaz. hebd. Méd. Chir., 1857, 4: 421-2; idem, Gaz. hôp. civ. milit., 1857, 30: 367 and 523. 


\section{An eighteenth-century medical hearing}

1792, under the name ulcus tropicum. (This year is also incorrect: it was 1788. . $^{43}$ Loudon, in two thorough and well-documented papers, has presented further evidence of the widespread occurrence of chronic leg ulcers in the eighteenth century both on land and at sea. Remarkably, these ulcers occurred, in distinction to what is seen today, predominantly among men and in those below the age of 40 . Loudon argues that vitamin C deficiency (scorbut) was a main conditioning factor, and refers to Sir Gilbert Blane and James Lind. The earliest surviving naval record (a surgeon's journal) that he found dates from $1793 .{ }^{44}$ The description by the VOC's opperchirurgijn Van Brakel antedates this by a substantial margin. Would it not only be fair to attach Van Brakel's name to this disease: "Van Brakel's ulcer" or "ulcus tropicum (Van Brakel)"?

\footnotetext{
${ }^{43}$ Judassohn, Handbuch, note 34 above. A search by Mr D. W. C. Stewart, Librarian of the Royal Society of Medicine, London, unearthed the first edition of the Observations on the diseases of the Army in Jamaica by the army physician John Hunter (1st ed. London, J. Johnson, 1788), ch. 6, pp. 275-83, in which the author reported on the high prevalence of leg ulcers among the soldiers there. The ulcer is usually induced by the bite of the jigger (chigger) flea, burying itself and depositing its eggs under the exposed skin of toes, feet, and lower legs, and in some cases by scratches and bruises, because the men went without shoes or stockings. A feeble constitution (scurvy) promotes the development of the fast-growing ulcers, which often lead to loss of toes and "caries" of bone, and are refractory to all kinds of attempted treatment. Hunter's book was translated into German in 1792. Hunter's description of the ulcer itself is not very detailed.

${ }^{44}$ I. S. L. Loudon, 'Leg ulcers in the eighteenth and early nineteenth centuries', J. roy. Coll. gen. Practitioners, 1981, 31: 263-273; idem, 'Leg ulcers in the eighteenth and early nineteenth centuries. II. Treatment', ibid., 1982, 32: 301-9.
} 